Assiut University web-site: www.aun.edu.eg

\title{
PARASITIC INFECTIONS AND HISTOPATHOLOGICAL CHANGES IN THE SQUEAKER FISHES, SYNODONTIS SERRATUS AND SYNODONTIS SCHALL FROM LAKE NASSER, EGYPT
}

\author{
AWATEF HAMED HAMOUDA \\ Fish Diseases Department, Faculty of Fish and Fisheries Technology, Aswan University, Aswan, Egypt
}

Received: 26 March 2019; $\quad$ Accepted: 30 April 2019

\begin{abstract}
This work describes the parasitic infections in wild Synodontis serratus and Synodontis schall from Lake Nasser, Egypt and the histopthological impacts of these parasites on the infected fish. A total number of 100 Synodontis serratus and 100 Synodontis schall were collected alive from several and various localities of the lake during 2018. One cestode: Wenyonia virilis, three nematodes: Cithariniella citharini, Procamallanus laeviconchus and Spirocamallanus pseudospiralis (new locality record) and one zoonotic encysted metacercaria of trematode: Centrocestus formosanus (new hosts record) were identified from both fish species; in addition to, one cestode: Proteocephalus sulcatus and one acanthocephalan: Rhadinorhynchus sp. (new host record) were only recorded from Synodontis schall. The infection rates of examined fish; Synodontis serratus and Synodontis schall were $54 \%$ and $78 \%$ respectively. This study evaluated clinical signs, postmortem lesions, organ or tissue susceptibility, incidence, intensity of infection, seasonal prevalence and histopathological alterations induced by these parasitic infections. Interestingly, the musculature of the fish was free from any parasitic infections and safe for human consumption provided that the fish would be eviscerated and adequately cooked. This work provides analysis of fish-parasite fauna which is a very helpful tool for implementing control and preventative measures against parasitic diseases especially the zoonotic ones.
\end{abstract}

Key words: Synodontis serratus, Synodontis schall, Spirocamallanus pseudospiralis, Centrocestus formosanus, Rhadinorhynchus sp.

\section{INTRODUCTION}

In the world there are 13,000 freshwater fish species, $25 \%$ of them are in African freshwater bodies (Lévêque et al., 2008). The catfish, Synodontis species of the family Mochokidae are freshwater tropical fish of high commercial value in most African countries; they inhabit rivers and lakes especially the Nile and its tributaries, and represent an important food fish (Bishai and Abu Gideiri, 1967; Steffens, 2006 and Eyo and Effanga, 2018).

Synodontis species are of the contemporary fish species in Lake Nasser after tilapias (the predominant species). They are small to medium sized fish, omnivorous, feeding mainly on animal food (fish, worms, mollusks and insects), some food of plant origin, phyto- and zooplankton (Bishai et al., 2000). They support the commercial fisheries in Egypt

Corresponding author: Dr. Awatef Hamed Hamouda

E-mail address: awatefhamouda@yahoo.com; awatefhamouda@aswu.edu.eg

Present address: Fish Diseases Department, Faculty of Fish and Fisheries Technology, Aswan University, Aswan, Egypt
(Mekkawy and Hassan, 2011). Synodontis serratus and Synodontis schall; are from the most common fish of family Mochokidae in Egypt, distributed in the whole River Nile and Lake Nasser. They popularly known as korkar, gargour or squeakers due to the sounds they make when removed from the water by rubbing their spines together (Latif, 1974 and Bishai and Khalil, 1997).

Parasites can act as severe pathogens competing for food with the fish host, thereby depriving them of essential nutrients and inhibiting their growth leading to morbidity or even mortality, rendering the fish more vulnerable to predators (Azadikhah et al., 2014 and Omeji et al., 2015) as well as, they may have zoonotic threats to animal and human consumers (Hamouda et al., 2018 and Hamouda, 2018). Centrocestus formosanus is a minute trematode species of family Heterophyidae which has zoonotic importance (Darwin and Fried, 2007 and Jong-Yil et al., 2013). It inhabits the intestine of piscivorous birds and mammals as final hosts while; the snails including Melanoides tuberculata act as the first intermediate hosts (Yousif et al., 2016); as well as, various species of freshwater fishes, frogs, and toads act as second intermediate hosts (Sohn and Chai, 
2005 and Han et al., 2008). However, human infections with this fluke have been documented so the zoonotic potential of this trematode should be regarded as a public health issue especially for humans eating undercooked or raw infected fish (Mehrdana, 2014). The parasitic infections of wild fish are common where the ecological requirements for intermediate hosts, final hosts and parasite transmission are met (Feist and Longshaw, 2008).

To date, there is dearth of information on parasitic diseases infecting Synodontis spp. especially in Egypt; most reports concern surveys on parasites of some fish species of Lake Nasser (El-Naffar et al., 1983 and Saoud and Wannas, 1984) as well as, some researchers focus on certain parasites as Moravec (1974 and 1994), Fahmy et al. (1976), Imam et al. (1991), Al-Bassel (2003) and Rabei (2009) so the fauna of parasitic infections in Synodontis serratus and Synodontis schall of Lake Nasser remains little known; this study was planned to investigate the parasites infecting these two fish species in the lake recording the clinical signs, postmortem lesions, organ or tissue susceptibility, prevalence, seasonal incidence, intensity and the histopathological changes induced by these detected parasites.

\section{MATERIALS AND METHODS}

\section{Study area and fish samples}

The present research was carried out in Lake Nasser (southern region of Egypt), located between latitudes $22^{\circ} 00^{\prime}-23^{\circ} 58^{\prime} \mathrm{N}$ and longitudes $31^{\circ} 19^{\prime}-33^{\circ} 19^{\prime} \mathrm{E}$, $900 \mathrm{~km}$ from Cairo.

A total number of 200 wild Mochokidae, 100 Synodontis serratus and 100 Synodontis schall (Table 1) were collected alive from various localities of Lake Nasser seasonally (25 fish of each species/season) from January to December 2018. Fish were transported as quickly as possible to the laboratory of Fish Diseases, Faculty of Fish and Fisheries Technology, Aswan University, for clinical and parasitological examinations.

\section{Clinical, postmortem and parasitological examinations}

The investigated fish were weighed and measured then they were euthanized rapidly by cervical dislocation prior to dissection according to AVMA (2013) (Research ethics committee of the University, approval no.12/2017). The procedure complies with national and local animal welfare laws, guidelines and policies. The fish were subjected to full clinical, postmortem and parasitological examinations according to the methods described by Noga (2010) and Eissa (2016).

Collected cestodes and acanthocephalans were left in the refrigerator at $4^{0} \mathrm{C}$ for few hours till complete relaxation, and then fixed in AFA (alcohol- formol acetic acid). For permanent preparation, they stained with acetic acid alum carmine, dehydrated in ascending grades of ethanol series, cleared and mounted in Canada balsam or DPX. The isolated nematodes were kept in glycerin alcohol $(70 \%$ ethanol plus $5 \%$ glycerol) then washed in $70 \%$ ethanol, cleared in lacto phenol and mounted in glycerol gelatin. Collected parasites were identified according to Khalil (1964), Arai (1989), Scholz and Salgado-Maldonado (2000), Moravec and Van As (2004), Ibraheem and Mackiewicz (2006), Scholz et al. (2009), and Moravec \& Scholz (2017).

Organ or tissue susceptibility, prevalence and seasonal incidence for each detected parasite were recorded.

Intensity of infection was recorded according to the following formula:

Intensity of infections $=$ total number of a particular parasite species in a sample of a host species / number of infected individuals of the host species in this sample.

Obtained results were statistically analyzed using the mean and the standard error of the mean (SEM) by using the IBM SPSS statistics version 22 (SPSS 2013).

\section{Histopathological examination}

Tissue specimens from intestine, stomach, liver, kidney, spleen and gills of the infected fish showing gross lesions were kept in $10 \%$ formalin and processed for histopathological evaluation, using the routine paraffin embedding method as described by Bancroft and Gamble (2007).

\section{RESULTS}

Clinical examination of Synodontis serratus and Synodontis schall revealed no pathognomonic lesions except presence of some hemorrhagic patches on different parts of infected fish's skin (Fig. 1 A) as well as, congested gills with excessive mucus secretions. The postmortem findings of naturally infected fish revealed severely congested stomach, intestine, liver, spleen and kidney (Fig. 1 C) especially in case of Proteocephalus sulcatus infection (Fig. 1 B). Visible parasites could be seen by naked eyes in the stomach and intestine. 

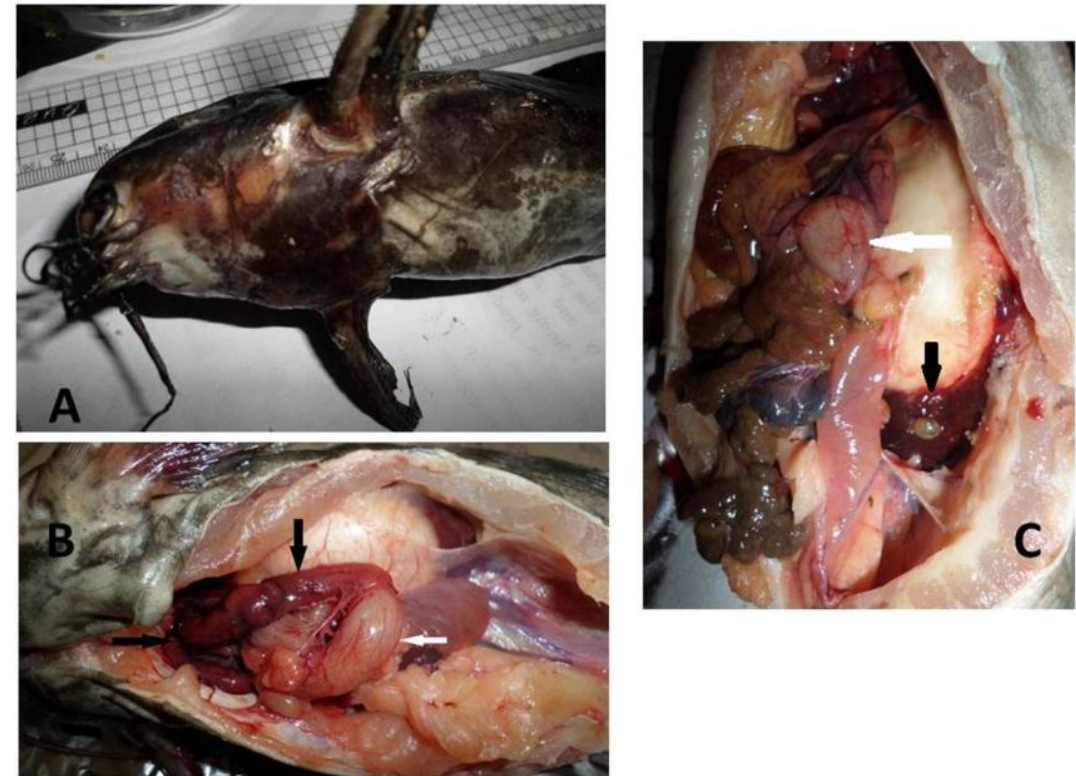

Fig. 1: A: Synodontis serratus infected with internal parasites showing hemorrhagic patches on the abdomen. B: Synodontis schall infected with Proteocephalus sulcatus, Cithariniella citharini and Procamallanus laeviconchus showing severely congested intestine (black arrows) and congested stomach (white arrow).

C: Synodontis serratus infected with Procamallanus laeviconchus showing congested stomach (white arrow) and kidney (black arrow).

The following parasites were identified, on the bases of the morphological examinations:

Wenyonia virilis (Woodland, 1923)

Host: Synodontis serratus and Synodontis schall
Wenyonia virilis is a Caryophyllidean tapeworm; has a monozoic body type, containing only a single set of male and female genital organs. The adult is elongated, dorsoventrally flattened and measuring 7$21 \mathrm{~mm}$ long. The scolex is conical, may be round to flatten in cross-section and approximately $10 \%$ of the total worm length (Fig. 2).
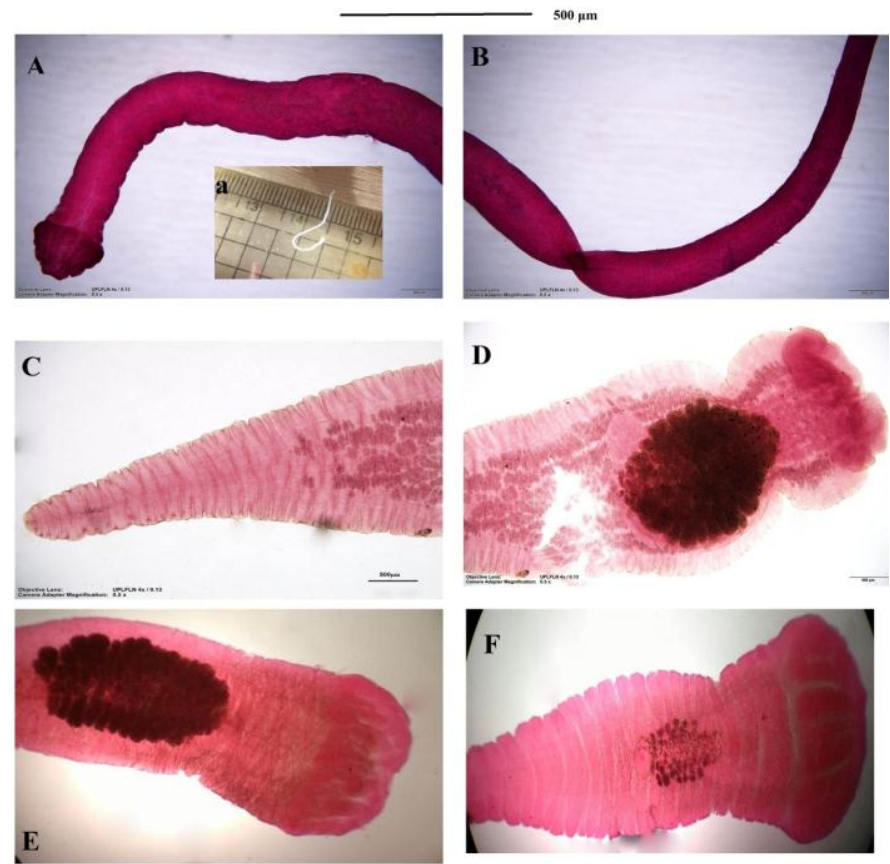

Fig. 2: Different developmental stages of Wenyonia virilis

A: Anterior end of adult stage stained with acetic acid alum carmine $\mathrm{x} 4$, a: Whole mature cestode.

B: Posterior end of adult stage stained with acetic acid alum carmine $\mathrm{x} 4$,

C, D, E and F: Different developmental stages stained with acetic acid alum carmine $\mathrm{x}$ 4. Scale bar $=500 \mu \mathrm{m}$. 


\section{Proteocephalus sulcatus (Goeze, 1782)}

Host: Synodontis schall

Proteocephalus sulcatus is a Proteocephalidean segmented tapeworm, their testes, ovary, vitelline follicles, and uterus are medullary. Immature proglottids are wider than long to square while mature proglottids are very few in number and slightly longer than wide. Scolex is unarmed, wider than neck with four suckers. Testes are medullary, spherical to oval, in 1 or 2 incomplete layers, forming 1 field between osmoregulatory canals and ovary. Ovary is bilobed, with very wide and short lobed lateral wings. (Fig.3).
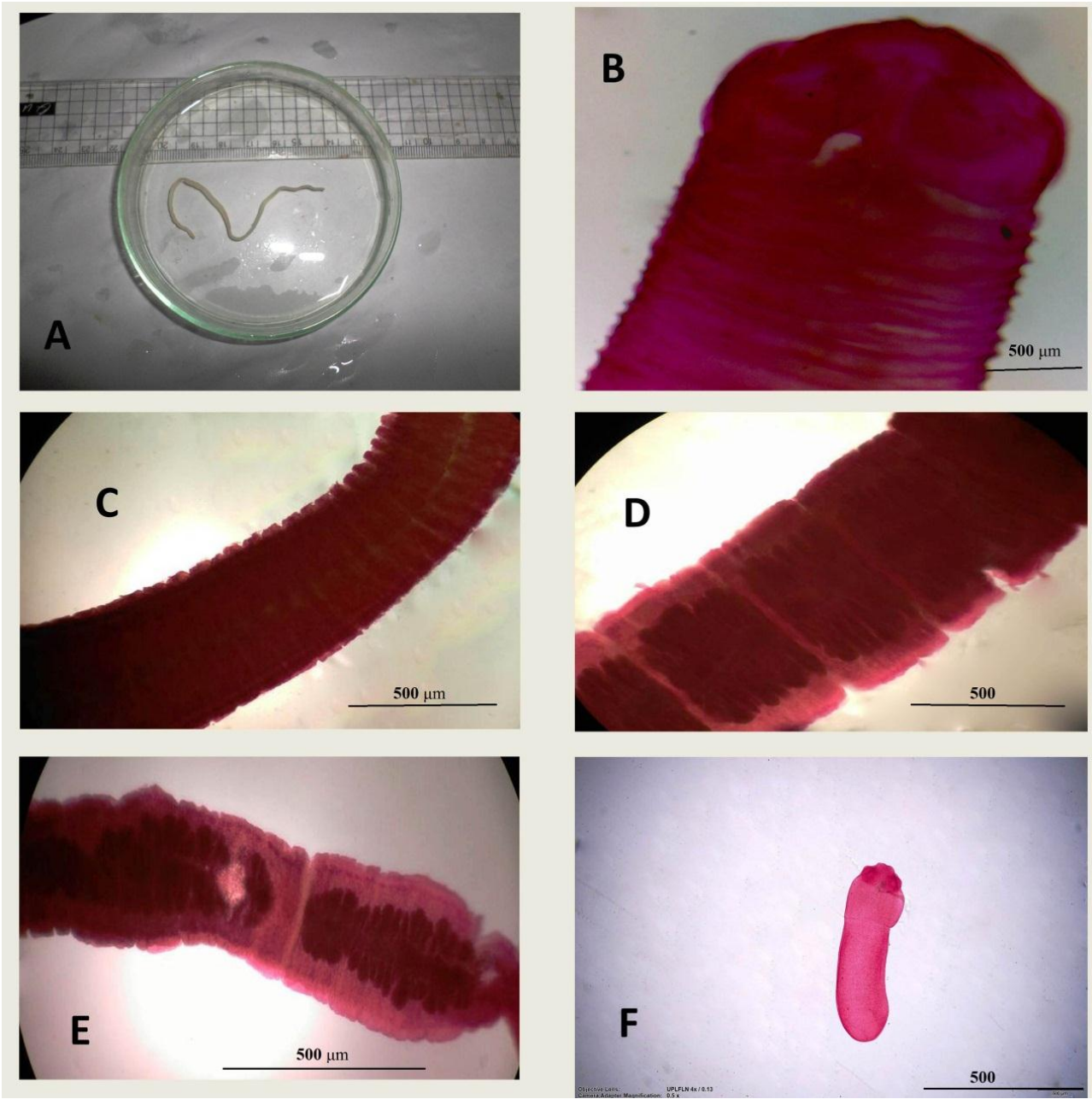

Fig. 3: Proteocephalus sulcatus

A: Whole, mature cestode.

B: Scolex stained with acetic acid alum carmine $\mathrm{x} 4$,

C and D: Immature segments stained with acetic acid alum carmine $x$,

E: Mature segments stained with acetic acid alum carmine x 4,

F: Small developmental stage stained with acetic acid alum carmine $\mathrm{x} 4$.

Scale bar $=500 \mu \mathrm{m}$.

Rhadinorhynchus sp. (Rudolphi, 1802)

Host: Synodontis schall

The acanthocephalan parasite; Rhadinorhynchus sp. is isolated for the first time from Synodontis schall of Lake Nasser and this may be a new host record. The male is white in color with long, cylindrical body, measuring up to 2 centimeters and has subcylindrical proboscis that enlarged slightly anteriorly, armed with 14-16 longitudinal rows of 26 hooks each and the ventral hooks of anterior two-thirds of proboscis are weaker, slightly shorter than others. Testes are elongate and tandem in posterior half of the trunk. Cement glands are nearly as long as both testes (Fig. 4). 

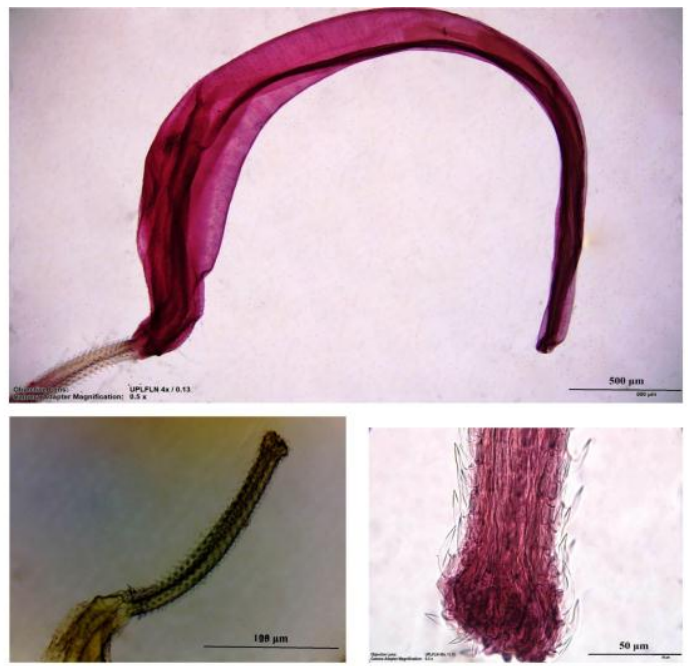

Fig. 4: Rhadinorhynchus sp. isolated from Synodontis schall:

A: Male stained with acetic acid alum carmine $\mathrm{x} 4$, scale bar $=500 \mu \mathrm{m}$.

B: Wet mount of anterior end $\mathrm{x} 20$, scale bar $=100 \mu \mathrm{m}$.

C: Proboscis showing arrangement of hooks stained with acetic acid alum carmine $\mathrm{x} 40$, scale bar $=50 \mu \mathrm{m}$.

Cithariniella citharini (Khalil, 1964)

Host: Synodontis serratus and Synodontis schall

Cithariniella citharini is very small nematode, measuring few millimeters, whitish in color and possess a delicate cuticle. The oesophagus is cylindrical, uniform in diameter and ends in a single bulb which separate by a constriction (isthmus) from the end of corpus. The intestine is straight and narrow. The female is longer than male measuring 6.5 $-7.5 \mathrm{~mm}$ long. The body become narrow behind the anal opening and forms a long pointed tail. There are
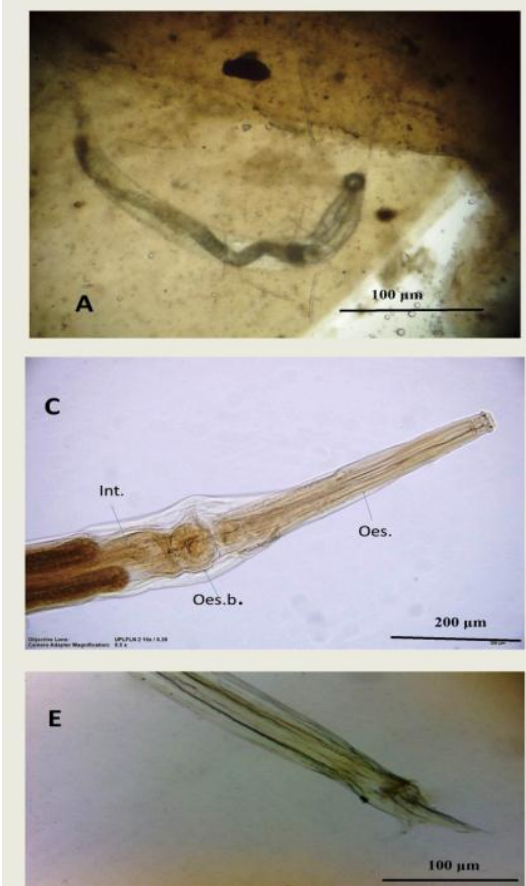

Fig. 5: Cithariniella citharini

two ovaries; the anterior is slightly below the bulb and the posterior in front of the vulva. The uteri are filamentous; coil and fill with eggs which are connect together with filaments inside the uterus. Eggs are immature, oval in shape, flat from one side and convex from the other. The male is small and strongly curved posteriorly, measuring $3.5-4.5 \mathrm{~mm}$ long. The tail is long, pointed and curved ventrally. A single testis is located anteriorly to a level slightly posterior to the excretory pore. A single spicule is present (Fig. $5)$.
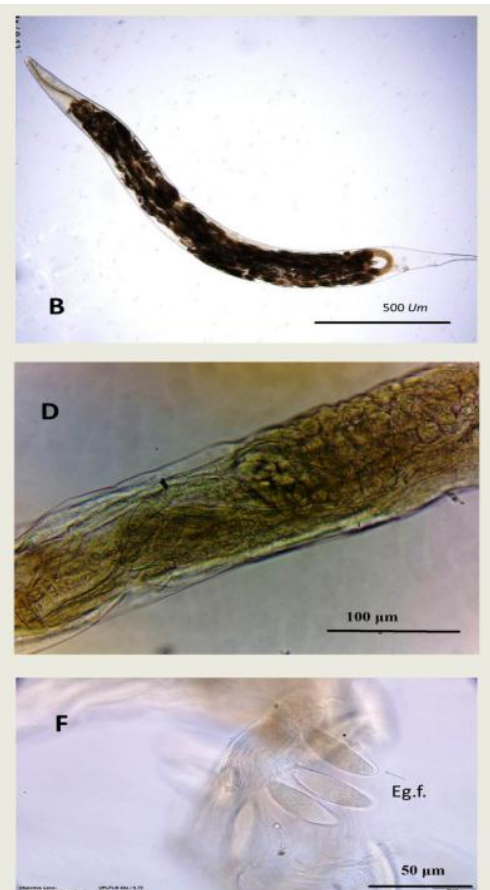

A: Whole nematode attached to the intestinal wall x 20, scale bar $=100 \mu \mathrm{m}$.

B: Whole mount $x 4$, scale bar $=500 \mu \mathrm{m}$.

C: Anterior end x 10, scale bar $=200 \mu \mathrm{m}$. Oes.; Oesophagus- Oes.B.; Oesophgeal bulb- Int; Intestine.

D: Middle part of female showing eggs inside it x 20, scale bar $=100 \mu \mathrm{m}$.

E: Posterior end of female $\mathrm{x} 20$, scale bar $=100 \mu \mathrm{m}$.

F: Eggs x 40, scale bar $=50 \mu \mathrm{m}$. Eg.f.; Egg filament 


\section{Procamallanus laeviconchus (Wedl, 1861)}

Host: Synodontis serratus and Synodontis schall

A small to medium-sized nematode, measuring 2.7$6.5 \mathrm{~mm}$ long with thick, roughly transversely striated cuticle. Live specimen is red in color. Buccal capsule is yellowish and barrel-shape. Muscular esophagus is slightly shorter than glandular esophagus. Males are smaller than gravid females. The two spicules of male are simple, with sharply pointed distal tips and the tail is conical, with rounded tip. The female uterus contains numerous coiled larvae. Anterior ovary is well developed, extend anteriorly to region of glandular esophagus and posterior ovary is absent. The female tail is conical, with 3 small finger-shaped processes (Fig. 6).
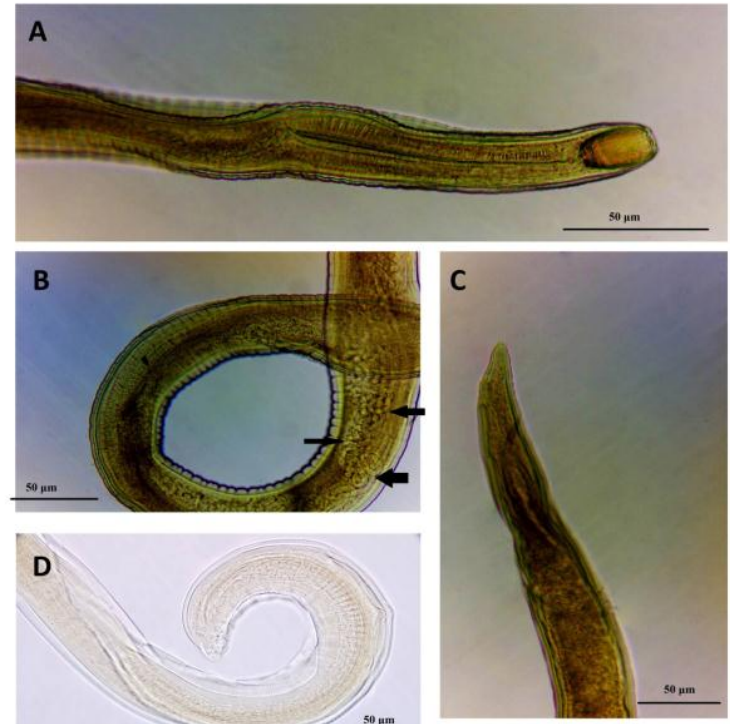

Fig. 6: Procamallanus laeviconchus

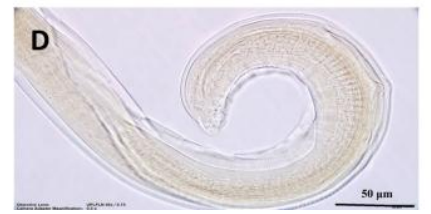

A: Anterior end $x$ 40,

B: Female's middle part filled with coiled larvae (arrows) x 40,

C: Posterior end of male x 40, D: Posterior end of female $\mathrm{x} 40$, scale bar $=50 \mu \mathrm{m}$.

Procamallanus (Spirocamallanus) pseudospiralis (Moravec and Scholz, 2017)

Host: Synodontis serratus and Synodontis schall

The nematode is medium-sized, measuring $2-2.5 \mathrm{~cm}$ long. Live worm is red in color resemble Procamallanus laeviconchus but longer than it and the buccal capsule is barrel-shaped, with 8-11 spiral ridges. The excretory pore is usually at level of anterior end of glandular esophagus. Tail of gravid female is conical, with short, abruptly narrowed distal end and tip is sharply pointed (Fig. 7). The present finding of this parasite represents new locality record.
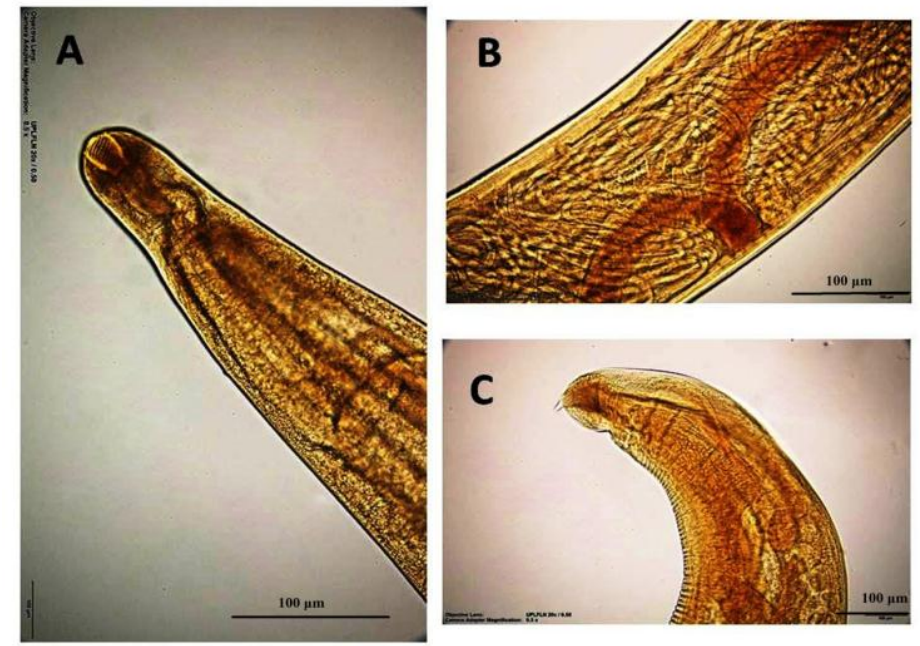

Fig. 7: Spirocamallanus pseudospiralis

A: Anterior end of female x 20, scale bar $=100 \mu \mathrm{m}$.

B: Female's middle part filled with coiled larvae $\mathrm{x} 20$, scale bar $=100 \mu \mathrm{m}$.

C: Posterior end of female x 20, scale bar $=100 \mu \mathrm{m}$. 
Encysted metacercariae (EMC) of Centrocestus formosanus

Host: Synodontis serratus and Synodontis schall

The encysted metacercariae are oval in shape, contain pear-shaped parasites with an X-shaped excretory bladder occupying the greater part of the posterior body. (Fig. 8). The present finding of this parasite represents new hosts record.

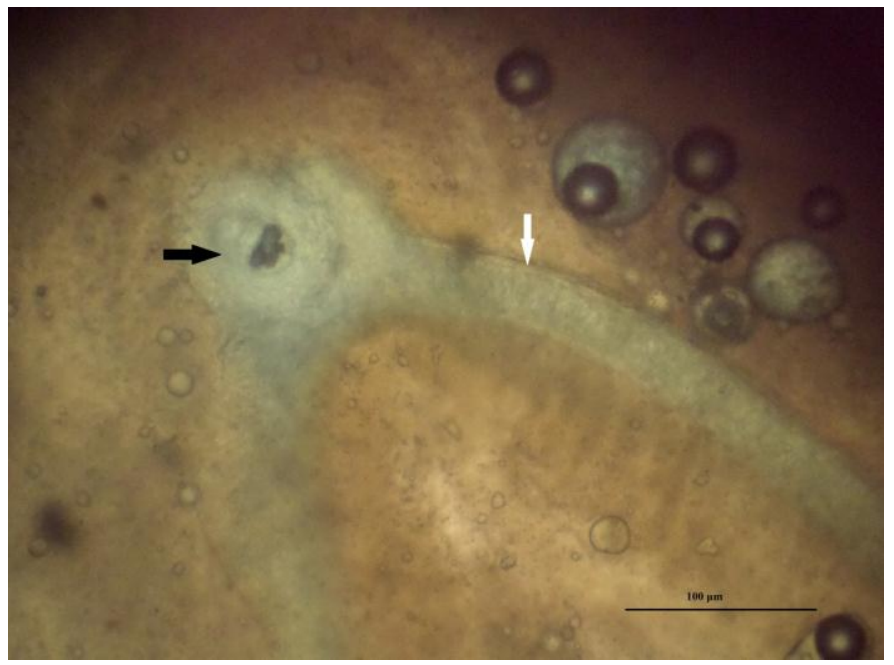

Fig. 8: EMC of Centrocestus formosanus (black arrow), migrating tunnel (white arrow) $\mathrm{x} 20$, scale bar $=100 \mu \mathrm{m}$.

Of the 100 Synodontis serratus examined, only 54\% recorded to be infected with at least one parasite while of the 100 Synodontis schall examined, $78 \%$ recorded to be infected with at least one parasite (Table 1).

Table 1: Examined fish species and total prevalence of infection during the period of January to December 2018.

\begin{tabular}{|c|c|c|c|c|c|}
\hline Fish species & $\begin{array}{c}\text { Weight } \\
(\mathrm{M} \pm \mathrm{SEM}) \mathrm{gm}\end{array}$ & $\begin{array}{c}\text { Length } \\
(\mathrm{M} \pm \mathrm{SEM}) \mathrm{cm}\end{array}$ & $\begin{array}{c}\text { No. of } \\
\text { examined fish }\end{array}$ & $\begin{array}{c}\text { No. of } \\
\text { infected fish }\end{array}$ & $\begin{array}{l}\text { Prevalence of } \\
\text { infection }\end{array}$ \\
\hline Synodontis serratus & $188.033 \pm 33.62$ & $25.33 \pm 2.06$ & 100 & 54 & 54 \\
\hline Synodontis schall & $373.20 \pm 111.64$ & $29.25 \pm 2.03$ & 100 & 78 & 78 \\
\hline
\end{tabular}

M (Mean), SEM (Standard error of the mean).

The intestine was the main target organ of infection for both fish species (Table 2, 3). The organ or tissue susceptibility, relative and intensity of parasitic infections in Synodontis serratus and Synodontis schall were summarized in Table 2, 3 respectively. Five parasitic species were detected in Synodontis serratus: Wenyonia virilis, Cithariniella citharini, Procamallanus laeviconchus, Spirocamallanus pseudospiralis and EMC of Centrocestus formosanus with prevalence of $25 \%, 40 \%, 36 \%, 12 \%$ and $23 \%$ respectively. Meanwhile, seven parasitic species were detected in Synodontis schall: Wenyonia virilis, Proteocephalus sulcatus, Rhadinorhynchus sp., Cithariniella citharini, Procamallanus laeviconchus,
Spirocamallanus pseudospiralis and EMC of Centrocestus formosanus with prevalence of $36 \%$, $60 \%, 7 \%, 44 \%, 23 \%, 5 \%$ and $11 \%$ respectively (Table 2, 3).

In this study, Cithariniella citharini was the most prevalent parasite in Synodontis serratus (40\%) while Proteocephalus sulcatus was the most prevalent in Synodontis schall (60\%) (Table 2, 3).

Cithariniella citharini was recorded to be the highest parasite intensity burden in Synodontis serratus and Synodontis schall with intensities of $12.32 \pm 1.92$ and $11.4 \pm 1.35$ respectively (Table 2,3 ). 
Table 2: Organ or tissue susceptibility, relative prevalence and intensity of parasitic infections in Synodontis serratus from Lake Nasser during the period of January to December 2018.

\begin{tabular}{|c|c|c|c|c|c|c|}
\hline \multirow{2}{*}{ Parasite Taxa } & \multirow{2}{*}{$\begin{array}{c}\text { Organ } \\
\text { susceptibility }\end{array}$} & \multirow{2}{*}{$\begin{array}{c}\text { No. of } \\
\text { examined fish }\end{array}$} & \multirow{2}{*}{$\begin{array}{c}\text { No. of } \\
\text { infected fish }\end{array}$} & \multirow{2}{*}{$\begin{array}{l}\text { Prevalence } \\
\text { of infection }\end{array}$} & \multicolumn{2}{|c|}{ Intensity of infection } \\
\hline & & & & & Min/Max & $(\mathrm{M} \pm \mathrm{SEM})$ \\
\hline \multicolumn{7}{|l|}{ CESTODA } \\
\hline Wenyonia virilis & Intestine & 100 & 25 & 25 & $1 / 7$ & $2.96 \pm 0.34$ \\
\hline \multicolumn{7}{|l|}{ NEMATODA } \\
\hline Cithariniella citharini & Intestine & 100 & 40 & 40 & $1 / 55$ & $12.32 \pm 1.92$ \\
\hline $\begin{array}{l}\text { Procamallanus } \\
\text { laeviconchus }\end{array}$ & $\begin{array}{l}\text { Stomach and } \\
\text { intestine }\end{array}$ & 100 & 36 & 36 & $1 / 7$ & $3.13 \pm 0.28$ \\
\hline $\begin{array}{l}\text { Spirocamallanus } \\
\text { pseudospiralis }\end{array}$ & Intestine & 100 & 12 & 12 & $1 / 3$ & $1.66 \pm 0.33$ \\
\hline \multicolumn{7}{|l|}{ TREMATODA } \\
\hline $\begin{array}{l}\text { EMC of Centrocestus } \\
\text { formosanus }\end{array}$ & Gills & 100 & 23 & 23 & $2 / 22$ & $10.6 \pm 0.22$ \\
\hline
\end{tabular}

Table 3: Organ or tissue susceptibility, relative prevalence and intensity of parasitic infections in Synodontis schall from Lake Nasser during the period of January to December 2018.

\begin{tabular}{|c|c|c|c|c|c|}
\hline \multirow{2}{*}{ Parasite Taxa } & \multirow{2}{*}{$\begin{array}{c}\text { Organ } \\
\text { susceptibility }\end{array}$} & \multirow{2}{*}{$\begin{array}{l}\text { No. of } \\
\text { examined } \\
\text { fish }\end{array}$} & $\begin{array}{l}\text { No. of } \\
\text { infected } \\
\text { fish }\end{array}$ & \multicolumn{2}{|c|}{ Intensity of infection } \\
\hline & & & $\begin{array}{l}\text { Prevalence } \\
\text { of } \\
\text { infection }\end{array}$ & Min/Max & $(\mathrm{M} \pm \mathrm{SEM})$ \\
\hline \multicolumn{6}{|l|}{ CESTODA } \\
\hline Wenyonia virilis & Intestine & 100 & 36 & $1 / 7$ & $3.02 \pm 0.26$ \\
\hline Proteocephalus sulcatus & Intestine & 100 & 60 & $1 / 6$ & $2.28 \pm 0.157$ \\
\hline \multicolumn{6}{|l|}{ ACANTHOCEPHALA } \\
\hline Rhadinorhynchus sp. & Intestine & 100 & 7 & $1 / 3$ & $1.57 \pm 0.29$ \\
\hline \multicolumn{6}{|l|}{ NEMATODA } \\
\hline Cithariniella citharini & Intestine & 100 & 44 & $2 / 40$ & $11.4 \pm 1.35$ \\
\hline $\begin{array}{l}\text { Procamallanus } \\
\text { laeviconchus }\end{array}$ & $\begin{array}{l}\text { Stomach and } \\
\text { intestine }\end{array}$ & 100 & 23 & $1 / 6$ & $2.82 \pm 0.29$ \\
\hline $\begin{array}{l}\text { Spirocamallanus } \\
\text { pseudospiralis }\end{array}$ & Intestine & 100 & 5 & $1 / 2$ & $1.2 \pm 0.20$ \\
\hline \multicolumn{6}{|l|}{ TREMATODA } \\
\hline $\begin{array}{c}\text { EMC of Centrocestus } \\
\text { formosanus }\end{array}$ & Gills & 100 & 11 & $2 / 15$ & $8.81 \pm 1.42$ \\
\hline \multicolumn{6}{|c|}{ EMC (Encysted metacercariae), Min (Minimum), Max (Maximum), M (Mean), SEM (Standard error of the mean) } \\
\hline $\begin{array}{l}\text { Higher infection rates of } \\
\text { Wenyonia virilis, Cit } \\
\text { Procamallanus laeviconc } \\
\text { spring ( } 48 \%, 72 \% \text { and } 52 \\
\text { Spirocamallanus pseud } \\
\text { Centrocestus formosanus } \\
\text { and } 32 \% \text { respectively) (Ta }\end{array}$ & $\begin{array}{l}\text { Synodontis se } \\
\text { ariniella citl } \\
\text { us were obse } \\
\text { b) respectively } \\
\text { spiralis and } \\
\text { prevailed in } \\
\text { le 4). }\end{array}$ & $\begin{array}{l}\text { ratus with } \\
\text { trini and } \\
\text { ved during } \\
\text { meanwhile } \\
\text { EMC of } \\
\text { inter }(24 \%\end{array}$ & \multicolumn{3}{|c|}{$\begin{array}{l}\text { In Synodontis schall, higher infection rates of } \\
\text { Wenyonia virilis, Cithariniella citharini and } \\
\text { Procamallanus laeviconchus were observed during } \\
\text { spring ( } 48 \%, 60 \% \text { and } 32 \%) \text { respectively. } \\
\text { Proteocephalus sulcatus showed a higher infection } \\
\text { rate in summer ( } 88 \% \text { ) while, Rhadinorhynchus sp. } \\
\text { recorded a higher infection rate in winter }(12 \%) \text {. } \\
\text { Spirocamallanus pseudospiralis showed higher } \\
\text { infection rates in both spring and autumn (8\%) for } \\
\text { each season. EMC of Centrocestus formosanus } \\
\text { revealed a higher infection rate in autumn (20\%) } \\
\text { (Table5). }\end{array}$} \\
\hline
\end{tabular}


Table 4: Seasonal incidence of parasitic infections among investigated Synodontis serratus from Lake Nasser during the period of January to December 2018 (number of fish in each season=25).

\begin{tabular}{lcccccccc}
\hline \multirow{2}{*}{ Parasites } & \multicolumn{8}{c}{ Seasons } \\
\cline { 2 - 10 } & \multicolumn{2}{c}{ Spring } & \multicolumn{2}{c}{ Summer } & \multicolumn{2}{c}{ Autumn } & \multicolumn{2}{c}{ Winter } \\
\cline { 2 - 10 } & No. & $\%$ & No. & $\%$ & No. & $\%$ & No. & $\%$ \\
\hline Wenyonia virilis & 12 & 48 & 8 & 32 & 3 & 12 & 2 & 8 \\
\hline Cithariniella citharini & 18 & 72 & 11 & 44 & 8 & 32 & 3 & 12 \\
\hline Procamallanus laeviconchus & 13 & 52 & 10 & 40 & 9 & 36 & 4 & 16 \\
\hline Spirocamallanus pseudospiralis & 3 & 12 & 2 & 8 & 6 & 24 & 1 & 4 \\
\hline EMC of Centrocestus formosanus & 5 & 20 & 6 & 24 & 8 & 32 & 4 & 16 \\
\hline EMC (Encysted metacercariae) & & & & & & & &
\end{tabular}

EMC (Encysted metacercariae)

Table 5: Seasonal incidence of parasitic infections among investigated Synodontis schall from Lake Nasser during the period of January to December 2018 (number of fish in each season=25).

\begin{tabular}{|c|c|c|c|c|c|c|c|c|}
\hline \multirow{3}{*}{ Parasites } & \multicolumn{8}{|c|}{ Seasons } \\
\hline & \multicolumn{2}{|c|}{ Spring } & \multicolumn{2}{|c|}{$\underline{\text { Summer }}$} & \multicolumn{2}{|c|}{$\underline{\text { Autumn }}$} & \multicolumn{2}{|c|}{$\underline{\text { Winter }}$} \\
\hline & No. & $\%$ & No. & $\%$ & No. & $\%$ & No. & $\%$ \\
\hline Wenyonia virilis & 12 & 48 & 10 & 40 & 9 & 36 & 5 & 20 \\
\hline Proteocephalus sulcatus & 18 & 72 & 22 & 88 & 17 & 51 & 3 & 12 \\
\hline Rhadinorhynchus sp. & 1 & 4 & 1 & 4 & 2 & 8 & 3 & 12 \\
\hline Cithariniella citharini & 15 & 60 & 12 & 48 & 10 & 40 & 7 & 28 \\
\hline Procamallanus laeviconchus & 8 & 32 & 7 & 28 & 3 & 12 & 5 & 20 \\
\hline Spirocamallanus pseudospiralis & 2 & 8 & 1 & 4 & 2 & 8 & 0 & 0 \\
\hline EMC of Centrocestus formosanus & 1 & 4 & 3 & 12 & 5 & 20 & 2 & 8 \\
\hline
\end{tabular}

EMC (Encysted metacercariae)

\section{Histopathological examination}

Gastric mucosa of Synodontis serratus infected with Procamallanus laeviconchus showed marked degenerative changes of the gastric glands (Fig. 9 A).

Gills of Synodontis serratus infected with Centrocestus formosanus showed nodular lesions associated with parasitic infestation in the cartilage of the gill filaments and revealed marked hyperplasia of the chondrocytes (Fig. 9 B, C).

Kidney of Synodontis serratus infected with Procamallanus laeviconchus, Cithariniella citharini and Centrocestus formosanus showed degeneration of the renal tubules and depletion of the melanomacrophages centers (Fig. 9 D); while the liver showed degeneration of the hepatocytes (Fig. 10 A) as well as, the spleen showed marked depletion of melanomacrophages centers (Fig. $10 \mathrm{~B}$ ).

The histopathological features of Synodontis schall's intestine infected with both Proteocephalus sulcatus and Cithariniella citharini showed severe congestion of the blood vessels within the lamina propria (Fig. $10 \mathrm{C}$ ) as well as, luminal necrotic mass was present (Fig. 10 D). The liver showed marked necrosis of the pancreatic portion (Fig. $11 \mathrm{~A}$ ); while the Kidney showed marked congestion, haemorrahge, tubular degeneration and interstitial leukocytic infiltration (Fig. $11 \mathrm{~B}, \mathrm{C}$ ). 

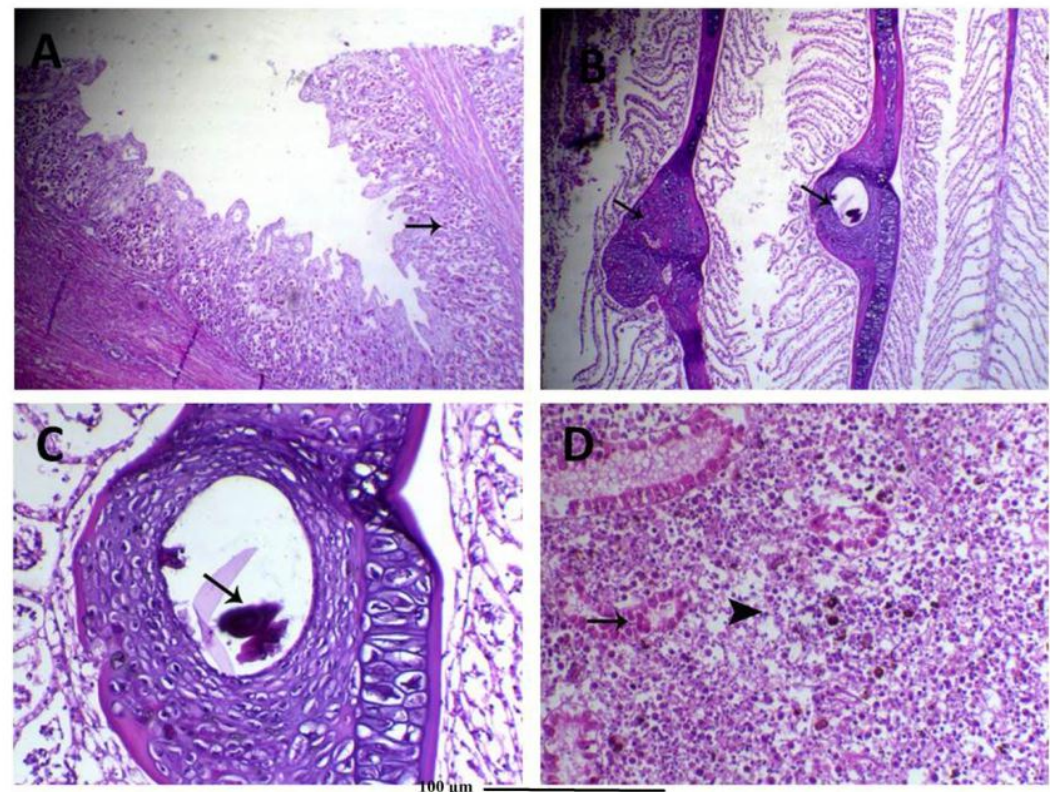

Fig. 9: A: Gastric mucosa of Synodontis serratus infected with Procamallanus laeviconchus showing marked degenerative changes of the gastric glands (arrow), H\&E, X100,

B: Gills of Synodontis serratus showing nodular lesions associated with skeletal EMC of Centrocestus formosanus (arrows), H\&E, X100,

C: Gills of Synodontis serratus showing nodular lesions associated with EMC of Centrocestus formosanus infestation in the cartilage of the gill filaments (arrow) and revealing marked hyperplasia of the chondrocytes, H\&E, X200,

D: Kidney of Synodontis serratus infected with Procamallanus laeviconchus, Cithariniella citharini and EMC of Centrocestus formosanus showing degeneration of the renal tubules (arrow) and depletion of the melanomacrophages centers (arrowhead), H\&E, X200, scale bar $=100 \mu \mathrm{m}$.
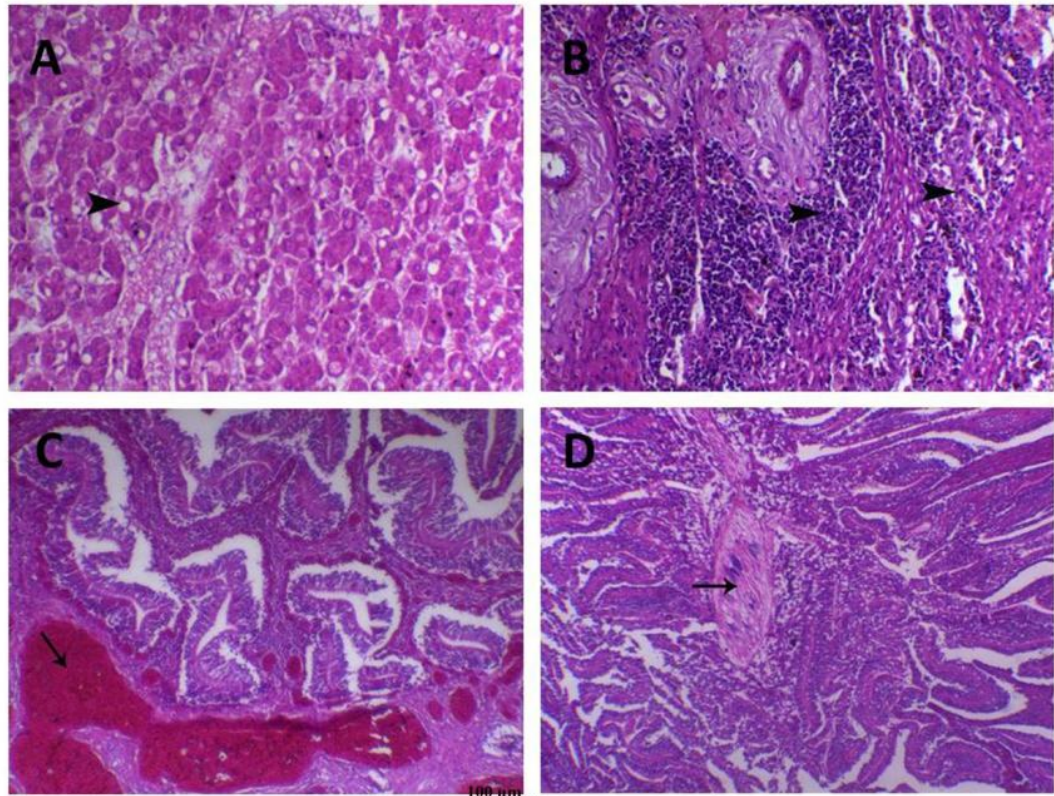

Fig. 10: A: Liver of Synodontis serratus infected with Procamallanus laeviconchus, Cithariniella citharini and EMC of Centrocestus formosanus showing degeneration of the hepatocytes (arrowhead indicates fatty changes), H\&E, X200,

B: Spleen of Synodontis serratus infected with Procamallanus laeviconchus, Cithariniella citharini and EMC of Centrocestus formosanus showing marked depletion of melanomacrophages centers (arrowheads), H\&E, X200, C: Intestine of Synodontis schall infected with Proteocephalus sulcatus and Cithariniella citharini showing severe congestion of the blood vessels within the lamina propria (arrow), H\&E, X100,

D: Intestine of Synodontis schall infected with Proteocephalus sulcatus and Cithariniella citharini showing luminal necrotic mass which may be related to dead parasite (arrow), H\&E, X100, scale bar $=100 \mu \mathrm{m}$. 

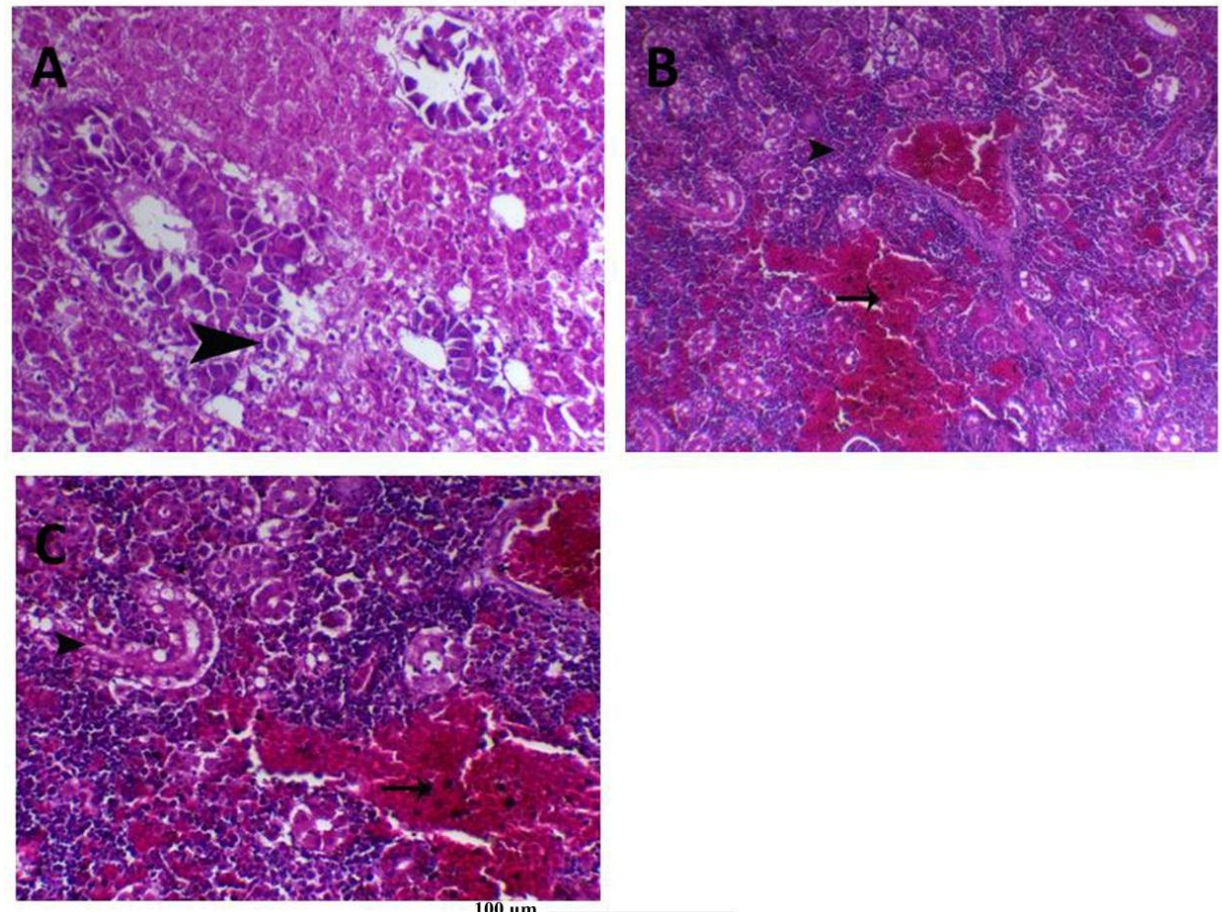

Fig. 11: Synodontis schall infected with Proteocephalus sulcatus and Cithariniella citharini:

A: Liver showing marked necrosis of the pancreatic portion (arrowhead), H\&E, X200,

B: Kidney showing marked congestion, haemorrahge (arrow) and interstitial leukocutic infiltration (arrowhead), H\&E, X 100,

C: Kidney showing marked haemorrahge (arrow), tubular degeneration (arrowhead) and interstitial leukocutic infiltration, H\&E, X200, scale bar $=100 \mu \mathrm{m}$.

\section{DISCUSSION}

Studies on parasitic fauna in the squeaker fishes; Synodontis serratus and Synodontis schall are still scarce especially in Egypt. Understanding the occurrence, organ or tissue susceptibility, relative prevalence, seasonal incidence, intensity and histopathplogical alterations induced by the parasites in these fish species is thus vital when implementing protective measures and planning disease management strategies (Subasinghe et al., 2001 and Crafford et al., 2014).

The detected cestodes, acanthocephalan, nematodes and trematode in the fish examined have complicated life cycles; as they need intermediate hosts such as snails, leeches and some crustaceans for propagation and transmission to fish (Paperna, 1996; Ferguson, 2011; Ramadan, 2012 and Hamouda, 2014). Hemorrhagic patches on different parts of the fish's body and congested gills were always found on the infected fish due to blood congestion and hemorrhages at the point of cercariae penetration and leeches attachment. Excessive mucus secretion may act as a defensive mechanism to diminish the irritant effect of the pathogen.

Severely congested intestine and stomach may be due to the detected parasites in intestine and stomach which embed themselves between the villi of the intestine and the lining mucosa of stomach causing local damage and may be peritonitis. Some helminthes produce toxic metabolic by-products which harm their hosts, causing occlusion of blood vessels, intestine and other ducts so internal organs revealed congestion and inflammation. Some adult worms discharged proteolytic enzymes, degrading the gastric and intestinal tissues (Woo, 1995).

Siluriform including Synodontis fish spp. are the most common hosts for cestodes in Africa. The first intermediate hosts of Caryophyllaeid cestodes are oligochaete worms, Tubifex and allied genera while first intermediate hosts of Proteocephalus are copepods, a second larval stage, pleurocercoids, develops in fish species non compatible as definitive hosts (Hoffman, 1967). All these hosts are available nearly all over the year in Lake Nasser and these clarify the high infection rate of cestodes in these fish species in the lake. The genus Wenyonia (Woodland, 1923) was reported only from Africa which involved eight species. Khalil and Polling (1997) reported three species of Wenyonia from the Nile: W. minuta; $W$. acuminate and $W$. virilis from Egypt. The morphological characteristics of the Wenyonia virilis parasite isolated in this study resembled the previously described W. virilis (Ibraheem and Mackiewicz, 2006 and Bjoern et al., 2011). Eighteen species of Proteocephalidean tapeworms have been described from freshwater fishes in Africa (De 
Chambrier et al., 2009) from which Proteocephalus sulcatus of this study resembled the previously recorded by De Chambrier et al. (2007); Scholz et al. (2009) and Azadikhah et al. (2014). Scholz et al. (2009) described Proteocephalus glanduligerus from Clarias cf. anguillaris from Sudan.

The morphological description of Rhadinorhnchus sp. reported in the present study was similar to that described by (Arandas Rego, 1987 and Arai, 1989) and it is the first time to detect it from Synodotis schall so it may be new host record. Acanthocephalans are thorny headed, worldwide distributed parasites; the adults inhabit the fish's intestine and feed on the intestinal walls (Alava and Aguirre, 2005). The infections of fish with Acanthocephalans revealed severe pathological lesions because of their hooked proboscis which attach to the host intestinal wall. They have complex life cycles, including arthropods as the intermediate hosts, fishes, birds, amphibians and mammals as the definitive hosts (Dudinak and Snabel, 2001) so it is normal to be found in the lake where all the ecological factors required for their hosts' propagation are available.

Cithariniella citharini was recorded by many authors from Synodontis spp. in Egypt (Moravec, 1974 \& 1994; Fahmy et al., 1976; El-Naffar et al., 1983; Imam et al., 1991; Al-Bassel, 2003 and Rabei, 2009) but Moravec and Van As (2015a) considered it Cithariniella khalili. Koubková et al. (2010) recorded three species of Cithariniella; C. citharini, C. khalili, and $C$. gonzalesi, from the squeaker (Mochokidae: Siluriformes) fishes from Senegal, West Africa.

Procarnallanus laeviconchus is one of the most prevalent and widespread nematodes in Africa, taking fish as final hosts and copepods as intermediate hosts (Moravec, 1974). It was described for the first time from Synodontis schall from Egypt by Wedl (1861). Later, it was recorded from different fish species including Clarias gariepinus and Bagrus bajad (Hamouda, 2018) while; Moravec \& Van As (2004) isolated it from Synodontis vanderwaali and $S$. nigromaculatus in Botswana.

Some authors consider that, Spirocamallanus is a subgenus of Procamallanus because it separated from it only by the presence of spiral thickening in the internal surface of buccal capsule of both sexes (Moravec and Sey, 1988 and Rodrigues et al., 1991) but others consider it as separate genus (Chabaud, 1975 and Petter, 1979). Moravec and Van As (2015b) recorded it from fishes of the Okavango River, Botswana while, Moravec and Scholz (2017) recorded Spirocamallanus pseudospiralis from Synodontis schall in the Sudan and the Democratic Republic of the Congo. To the best of our knowledge, there have been no published reports on isolation of
Spirocamallanus pseudospiralis from Synodontis spp. and other fish species of Lake Nasser, so it is considered new locality record.

In this study, EMC of Centrocestus formosanus were found in the gill filaments of Synodontis serratus and Synodontis schall of Lake Nasser for the first time recording new hosts record and adding these fish to the actually known second intermediate hosts for these parasites. Saad (1994) isolated Centrocestus unequiorchalis $\mathrm{n}$. sp. from the gills of Oreochromis niloticus at Aswan governorate and Hamouda (2018) isolated EMC of Centrocestus formosanus from the gills of Bagrus bajad from Lake Nasser. Morphological identification of Centrocestus formosanus EMC was similar to that recorded by (Abd Al-Aal et al., 2008; Reda et al., 2010; Hamouda, 2014 and Hamouda, 2018).

It is worth mentioning that, Lake Nasser is rich in insect larvae, mollusks, oligochaetes, snails, freshwater shrimps and many others (Bishai et al., 2000) which act as first intermediate hosts for the detected parasites, as well as, fish as second intermediate host in some cases and finally piscivorous birds, fish and reptiles as definitive final hosts. This may explain the high parasitic group burden in the examined Synodontis serratus (54\%) and Synodontis schall (78\%) in addition to, the omnivore nature of the examined fish.

In the present work, the intestine was the most susceptible organ of infection for both investigated fish species and this may be due to the fact that alimentary canal is a primary route of infection in fish and other vertebrates (Ringo et al., 2007). The GIT may provide ease of access for the pathogens with relatively non- aggressive immune response of the host; and availability of attachment sites and access to nutrients (Secombes and Chappell, 1996).

In the present study, Wenyonia virilis was recorded with total prevalence of $25 \%$ and $36 \%$ from Synodontis serratus and Synodontis schall respectively and this result was nearly similar to those recorded by El-Naffar et al. (1983) who recorded Wenyonia virilis from Synodontis serratus and Synodontis schall with prevalence of $31.3 \%$ and $32.5 \%$ respectively from Lake Nasser while, Saoud \& Wannas (1984) did not report any cestotal infections in these two fish species of the lake. Ibraheem and Mackiewicz (2006) recorded the immature stages of Wenyonia virilis from Synodontis schall at the River Nile, Egypt with prevalence of $44 \%$.

Proteocephalus sulcatus was recorded from Synodontis schall with prevalence of $60 \%$ and this result was nearly similar to that recorded by El-Naffar et al. (1983) who recorded it from Synodontis schall of Lake Nasser with prevalence of $65.7 \%$. 
Cithariniella citharini was recorded with total prevalence of $40 \%$ and $44 \%$ from Synodontis serratus and Synodontis schall respectively with intensities of $12.32 \pm 1.92$ and $11.4 \pm 1.35$ respectively. This result was higher than that recorded by El-Naffar et al. (1983) who recorded it from Synodontis serratus and Synodontis schall with prevalence of $26.6 \%$ and $28.5 \%$ respectively and lower than recorded by Rabei (2009) who isolated it from Synodontis schall of Lake Nasser with prevalence of $65.1 \%$ and worm burden varied from $10-50$ per host.

Procarnallanus laeviconchus was recorded with prevalence of $36 \%$ and $23 \%$ from Synodontis serratus and Synodontis schall respectively with intensities of $3.13 \pm 0.28$ and $2.82 \pm 0.29$ respectively and this result was somewhat different than that recorded by Dougnon et al. (2012) who isolated it from Synodontis schall with prevalence of $32.1 \%$ from South Benin and Omeji et al. (2015) who recorded it from S. Schall with prevalence of $7.33 \%$ from Nigeria. Moravec and Scholz (2017) recorded it from S. Schall in the River Nile, Sudan (one fish infected from the two examined fish with intensity of 7).

Spirocamallanus pseudospiralis isolated from Synodontis serratus and Synodontis schall with prevalence of $12 \%$ and $5 \%$ respectively with intensities of $1.66 \pm 0.33$ and $1.2 \pm 0.20$ respectively. Moravec and Scholz (2017) recorded it from S. Schall in the River Nile, Sudan (the two examined fish were infected with intensity of 7 and 12 per fish.

EMC of Centrocestus formosanus was isolated with prevalence of $23 \%$ and $11 \%$ from Synodontis serratus and Synodontis schall respectively.

Some of the detected parasites were of nearly uniform frequency during the different seasons; most probably due to high temperature in the lake is maintained nearly throughout the year. This favors the development of snails, invertebrate hosts and the final hosts (fish, crocodiles, frogs, snakes and aquatic birds).

The histopathology induced by Centrocestus formosanus infected the gills of Synodontis serratus was identical to that recorded by Mehrdana et al. (2014) who recorded cartilage hypertrophy, epithelial and mucous cell hyperplasia, clubbing and lamellar fusion associated with EMC of Centrocestus sp. infected Xiphophorus maculatus fish. Rezaie et al. (2017) reported severe damages and fusions of the gills of grass carp and common carp infected with Centrocestus formosanus as well as, Hamouda (2018) recorded the same lesions from Bagrus bajad infected with Centrocestus formosanus. Infections with EMC of Centrocestus formosanus associated with structural and functional damages of gills with a lower tolerance to hypoxia and a decrease respiratory efficiency (Paperna, 1991 and Santiago Bass et al., 2007) so, these parasites have adverse effects on fish leading to significant economic losses in fish industry.

The histopathological lesions induced by Proteocephalus sulcatus and Cithariniella citharini infected Synodontis schall's intestine were somewhat similar to that recorded by Azadikhah et al. (2014) who reported the pathological changes induced by Proteocephalus sulcatus infecting European catfish (Silurus glanis) from Iran as mechanical damages and inflammation of the intestine.

The results in this study may differ completely or partially with many studies and this could be attributed to abiotic and biotic conditions of the environments where the studies were carried.

\section{CONCLUSION}

In conclusion, the present work provides the first recent study in details on parasitic infections in wild Synodontis serratus and Synodontis schall from Lake Nasser. It is of great interests that, the two examined fish species harbor EMC of Centrocestus formosanus in their gills which have adverse effects confirmed histopathologically on infected fish as well as, they also have a zoonotic potential and may be considered a public health threat, if raw or inadequately processed fish are ingested so evisceration of fish after catching and adequately cooking are recommended. The disposal of infected fish parts or viscera in water should be prohibited. Extended investigations about the impacts of the detected parasitic infections on survival, gross rate, fecundity and immunity of the two fish species are recommended to ensure successful fishery management plans. Further studies on Rhadinorhynchus sp. (new host record), Spirocamallanus pseudospiralis (new locality record) and the zoonotic Centrocestus formosanus (new hosts record) are needed and urged. The fish musculature was free from parasitic infection and safe for human consumption. Fish-parasite fauna analysis is very helpful for implementing preventative and control measures against parasitic diseases. This study will be a useful tool for further advanced investigations about the detected parasites.

\section{Compliance with ethical standards}

\section{Ethics approval}

This work was approved by the ethics approval form (12/2017).

\section{Conflict of interest}

Author declared that there is no any conflict of interest. 


\section{REFERENCES}

Abd Al-Aal, Z.; Amer, O.H.; Badawy, A.I. and ElAshram, A.M. (2008): Digenetic trematodes of the little egret, Egretta garzetta and possibility of transmission to Oreochromis niloticus at ElAbbassa fish farms, Egypt. $8^{\text {th }}$ International Symposium on Tilapia in Aquaculture 13511364.

Alava, J.J. and Aguirre, W.E. (2005): Scanning electron microscopy of Neoechinorhynchus sp. (Acanthocephala: Neoechinorhynchidae), a possible new species of intestinal parasite of the Tall fin croaker Micropogonias altipinnis (Günther, 1864). Parasitol Latinoam 60, 48-53.

Al-Bassel, D.A.H. (2003): A general survey of the helminth parasites of fish from inland waters in the Fayoum Governorate, Egypt. Parasitol. Res. 90: 135-139.

Arai, H.P. (1989): Acanthocephala, p. 1-90. In L. Margolis and Z. Kabata [ed.]. Guide to the parasites of fishes of Canada. Part III. Can. Spec. Publ. Fish. Agnat. Sci. 107: 95 p.

Arandas Rego, A. (1987): Rhadinorhnchus pristis (Rudolphi, 1802) Acanthocephalan parasite of fishes, Scomber scombrus and S. Japonicus. Some observations on the scanning electron microscope. Mem. Inst. Oswaldo Cruz. Riode Janeiro 82(2): 287-288.

AVMA (2013): American Veterinary Medical Association: guidelines for the euthanasia of animals (2013 ed.). Schaumburg, Illinois: American Veterinary Medical Association.

Azadikhah, D.; Nekuie Fard, A.; Seidgar, M. and Amin, H. (2014): The infection rate and pathologic lesions induced by Proteocephalus osculates (Goeze, 1782) in European catfish (Silurus glanis) from North-west of Iran. Bull. Env. Pharmacol. Life Sci. Vol 3 [Spl Issue V]: 63-68.

Bancroft, J.D. and Gamble, M. (2007): Theory and practice of histological techniques, 5th ed. Churchill Livingstone, London, pp 125-138.

Bishai, H.M. and Abu Gideiri, Y.B. (1967): Studies on the biology of the genus Synodontis at Khartoum. IV. Zool. Bot. Afr. LXXV: 17-30.

Bishai, H.M. and Khalil, M.T. (1997): Freshwater fishes of Egypt. Department of Nature Protection, Publication of National Biodiversity Unit, No. 9, Egyptian Environmental Affairs agency (EEAA), Cabinet of Ministers, Egypt, pp:229.

Bishai, H.M.; Abdel-Malek, S.A. and Khalil, M.T. (2000): Lake Nasser A treatise, Publication of National Biodiversity Unit. No.11.2000. Arab Republic of Egypt Cabinet of Ministers, Egyptian Environmental Affairs Agency (EEAA), Department of Nature Protection.

Bjoern, C.S.; Miloslav, J.; Zuheir, N.M. and Tomas, S. (2011): Revision of Wenyonia Woodland, 1923 (Cestoda: Caryophyllidea) from catfishes
(Siluriformes) in Africa. Syst Parasitol 79:83107.

Chabaud, A.G. (1975): Keys to gonera, of the order Spirurida,. Part 1. Camallanoidea, Draounculoidea" Gnathostomatoidea, Phy salopteroidea" Riotulaoridea, and Thelazioidea. CIH Keys to the nematode parasites of vertebrates 3. Commonwealth Agrioult. Bureaux, Farnbam Royal,Buoks, 27 pp.

Crafford, D.; Luus-Powell, $W$. and AvenantOldewage, A. (2014): Monogenean parasites from fishes of the Vaal Dam, Gauteng Province, South Africa II. New locality records. Acta Parasitologica 59(3), 485-492; ISSN 1230-2821. DOI: 10.2478/s11686-0140271-x

Darwin, M.K. and Fried, B. (2007): Food-borne Parasitic Zoonoses. Fish and Plant-Borne Parasites. Springer Science_Business Media, LLC, USA.

De Chambrier, A.; Scholz, T.; Beletew, M. and Mahmoud, Z.N. (2007): Redescription of Proteocephalus sulcatus (Klaptocz, 1906) (Cestoda: Proteocephalidea), a poorly known parasite of Clarotes laticeps (Pisces: Siluriformes) in the Sudan. Revue Suisse De Zoologie 114 (4): 693-702.

De Chambrier, A.; Scholz, T.S.; Beletew, M. and Mariaux, J. (2009): A new genus and species of Proteocephalidean (Cestoda) from Clarias catfishes (siluriformes: Clariidae) in Africa. J. Parasitol. 95(1), 2009, pp. 160-168.

Dougnon, J.; Montchowui, E.; Dadjo Daga, F.; Hovessionon, J.; Laleye, Ph. and Sakiti, N. (2012): Cutaneous and Gasterointestinal Helminth Parasites of the Fish Synodontis schall and Synodontis nigrita (Siluriformes: Mochkidae) from the Lower Queme Valley in South Benin. Research Journal of Biological Science 7(8): 320-326.

Dudiňák, V. and Snábel, V. (2001): Comparative analysis of slovak and czech populations of Pomphorhynchus laevis (Acanthocephala) using morphological and isoenzyme analyses. Acta Zoologica Universitatis Comenianae. 44: 41-50.

Eissa, A.E. (2016): Clinical and Laboratory Manual of Fish diseases. LAP LAMBERT Academic Publishing, Germany.

El-Naffar, M.K.; Saoud, M.E. and Hassan, I.M. (1983): A general survey of helminth parasites of some fish from Lake Nasser at Aswan, Egypt. Assiut Vet. Med. J. 11 (2): 141-148.

Eyo, V.O. and Effanga, E.O. (2018): Ectoparasitic infestation of the Nile Squeaker, Synodontis schall (Bloch and Schneider, 1801) from the Cross River Estuary, Nigeria. Int. J. Aquat. Biol. 6(1): 37-43.

Fahmy, M.A.M.; Mandour, A.M. and El-Naffar, M.K. (1976): On some nematodes parasites from the 
freshwater fishes in Assiut Province, Egypt. Veter. Med. J. 24: 263-276.

Feist, S.W. and Longshaw, M. (2008): Histopathology of fish parasite infections - importance for populations. Journal of Fish Biology 73: 21432160.

Ferguson, J.A. (2011): Impacts of multispecies parasitism on coho salmon (Oncorhynchus kisutch) in Oregon. Ph. D. thesis, Oregon State University.

Hamouda, A.H. (2014): Studies on the trematodal and cestodal diseases in cultured freshwater fish in Kafr El-Sheikh Governorate. Ph.D. Thesis, Faculty of Veterinary Medicine, Kafrelsheikh University, Egypt.

Hamouda, A.H. (2018): Epizootiological Studies on Some Parasitic Infections in Bagrus bajad from Lake Nasser, Egypt. Alexandria Journal of Veterinary Sciences 58(1): 40-47.

Hamouda, A.H.; Sorour, Sh.S.; El-Habashi, N.M. and El-Hussein, A.A. (2018): Parasitic Infection with Emphasis on Tylodelphys spp. as New Host and Locality Records in Nile Perch; Lates niloticus from Lake Nasser, Egypt. World Veterinary Journal 8(1): 19-33.

Hoffman, G.L. (1967): Parasites of North American Freshwater Fishes. University of California Press, Berkeley \& Los Angeles.

Han, E.T.; Shin, E.H.; Phommakorn, S.; Sengvilaykham, B.; Kim, J.L.; Rim, H.J. and Chai, J.Y. (2008): Centrocestus formosanus (Digenea: Heterophyidae) Encysted in the Freshwater Fish, Puntius brevis, from Lao PDR.”, Korean J Parasitol 46 (1): 49-53.

Secombes, C.J. and Chappell, L.H. (1996): Fish immune responses to experimental and natural infection with helminth parasites. Annual Review of Fish Diseases 6: 167-177.

SPSS (2013): IBM SPSS Statistics for Windows, Version 22.0. IBM Corp. Released 2013. Armonk, NY: IBM Corp.

Ibraheem, M.H. and Mackiewicz, J.S. (2006): Scolex development, morphology and mode of attachment of Wenyonia virilis Woodland, 1923 (Cestoidea, Caryophyllidea). Acta Parasitologica 51(1):51-58. ISSN 1230-2821

Imam, E.A.; El-Askalany, M.A. and Rashad, S.M. (1991): The helminth parasites of Synodontis schall and Bagrus bayad from Beni-Suef water resources. Assiut Vet. Med. J. 24: 137152.

Jong-Yil, C.; Woon-Mok, S.; Tai-Soon, Y.; Keeseon, S.; Duk-Young, M.; Mi Youn, L.; Hyemi, L.; Bounnaloth, I.; Bounlay, Ph. and Han-Jong, R. (2013): Centrocestus formosanus (Heterophyidae): Human Infections and the Infection Source in Lao PDR. Journal of Parasitology 99(3): 531- 536.

Khalil, L.F. (1964): Cithariniella citharini n. gen., n. sp. (Nematoda) an Oxyurid from freshwater fish Citharinus citharus in Sudan. J. Helminth. $38(1 / 2): 41-46$.

Khalil, L.F. and Polling, L. (1997): Check list of the helminth parasites of African freshwater fishes. Department of Zoology/Biology, University of the North, Pietersburg, Republic of South Africa.

Koubková, B.; Baruš, V. and Iveta, H. (2010): Nematodes of Cithariniella (Pharyngodonidae) from freshwater fishes in Senegal, with a key to species. Helminthologia 47(2): 105-114. DOI: $10.2478 / \mathrm{s} 11687-010-0017-8$

Latif, A.F.A. (1974): Fisheries of Lake Nasser. Aswan Regional Planning; Lake Nasser Development Centre, Aswan, Egypt, PP: 235.

Lévêque, C.; Oberdorff, T.; Paugy, D.; Stiassny, M.L.J. and Tedesco, P.A. (2008): Global diversity of fish (Pisces) in freshwater. Hydrobiologia 595: 545-567.

Mehrdana, F.; Jensen, H.M.; Kania, P.W. and Buchmann, K. (2014): Import of exotic and zoonotic trematodes (Heterophyidae: Centrocestus sp.) in Xiphophorus maculatus: Implications for ornamental fish import control in Europe. Acta Parasitologica 59 (2): 276-283; ISSN 1230-2821. DOI: 10.2478/ s11686-014-0237-z

Mekkawy, I.A.A. and Hassan, A.A. (2011): Some reproductive parameters of Synodontis schall (Bloch and Schneider, 1801) from the River Nile, Egypt. Fish. Aquat. Sci. 6: 456471.

Moravec, F. (1974): On some nematodes from Egyptian freshwater fishes. Acta Soc. Zool. Bohemoslov. 38: 32-51.

Moravec, F. (1994): Structure of the cephalic end in the genus Cithariniella Khalil, 1964 (Nematoda: Pharyngodonidae) as revealed by SEM, with a key to pharyngodonid genera from fishes. Syst. Parasitol. 27: 133-137.

Moravec, F. and Scholz, T. (2017): Some nematodes, including two new species, from freshwater fishes in the Sudan and Ethiopia. Folia Parasitologica 64: 010. Doi: 10.14411/ fp. 2017.010

Moravec, F. and Sey, O. (1988): Nematodes of freshwater fishes from North Vietnam. Part 1. Camallanoidea and Habronematoidea. Vest. cs. Spolec. zool. 52: 128-148.

Moravec, F. and Van As, J.G. (2004): Nematodes from the squeaker fishes Synodontis nigromaculatus and S. vanderwaali from the Okavango River, Botswana, including three new species. Systematic Parasitology 59: 169187.

Moravec, F. and Van As, L.L. (2015a): Studies on ascaridid, oxyurid and enoplid nematodes (Nematoda) from fishes of the Okavango River, Botswana. Folia Parasitologica 62: 039.

Moravec, F. and Van As, L.L. (2015b): Procamallanus (Spirocamallanus) spp. 
(Nematoda: Camallanidae) from fishes of the Okavango River, Botswana, including $P$. (S.) serranochromis n. sp. parasitic in Serranochromis spp. (Cichlidae). Syst Parasitol 90:151-164. DOI 10.1007/s11230014-9542-z

Noga, E.J. (2010): Fish diseases, diagnosis and treatment. 2nd ed. Iwa State University, Press, Ames.

Omeji, S.; Obande, R.A. and Member, S.T. (2015): Prevalence of Endoparasites of Synodontis shcall and Synodontis ocellifer (Upside-Down Catfish) from Lower River Benue, Nigeria. International Journal of Animal Biology 1(5): 176-181.

Paperna, I. (1991): Parasites infections and diseases of fish in Africa. CIFA committee for inland fisheries of Africa.

Paperna, I. (1996): Parasites, infections and diseases of fishes in Africa - An update CIFA Technical Paper. No.31. Rome, FAO.

Petter, A.J. (1979): Essai de classification de la sousfamille des Procamallaninae (Nematoda, Camallanidae). Bulletin du Museum National d'Historie Naturelle Section A Zoologie 1: 991-1008.

Rabei, G.M. (2009): Light and Scanning Electron Microscopy studies on Contracaecum sp. larvae and Cithariniella citharini (Nematoda) from Lake Nasser fishes. M. V. Sc. Thesis, Faculty of Science, Aswan, South Valley University, Egypt

Ramadan, R.A.M. (2012): Critical role of Cyclops strenus in the biology of Polyonchobothrium clarias (Cestoda) parasitizing cultured (Clarias garipenus). Egyptian Journal for Aquaculture 2 (1):93-103.

Reda, R.M.; El-Nobi, G.A.; Hassanin, M.E.; El-Hady, M.A. and El-Bouhy, Z.M. (2010): Study on some encysted metacercaria"digenetic trematodes" affecting gills of oreochromis niloticus. $10^{\text {th }}$ Csi. Vet. Med. Zag. Conference (10-13 febreuary 2010), Luxor.

Rezaie, A.; Dezfuly, Z.T.; Mesbah, M. and Ranjbar, A. (2017): Histopathologic report of infestation by Centrocestus formosanus in Iranian grass carp and common carp. Iran. J. Vet. Sci. and Technol. 9(1): 49-53.

Ringo, E.; Myklebust, R.; Mayhew, T.M. and Olsen, R.E. (2007): Bacterial translocation and pathogenesis in the digestive tract of larvae and fry. Aquaculture 268: 251-264.

Rodrigues, H.O.; Pinto, R.M. and Noronha, D. (1991): Key to the species of Brazilian Procamallanus with general considerations (Nematoda, mallanoidea). Memórias do Instituto Oswaldo Cruz 86: 107-113.

Saad, A.I. (1994): The life cycle of Centrocestus unequiorchalis n. sp. (Heterophyidae: Centrocestiinae). J. Islamic Acad. Sci. 7 (3): 193-198.
Santiago Bass, C.; Khan, S. and Weis, J.S. (2007): Morphological changes to the gills of killifish associated with severe parasite infection. Journal of Fish Biology 71, 920-925. DOI: 10.1111/j.1095-8649.2007.01532.x

Saoud, M.F. and Wannas, M.Q. (1984): A qualitative and quantitative survey on the helminth parasites of fishes from the Aswan High Dam Lake in Egypt. Qatar Univ. Sci. Bull. (1984) 4: 129-142.

Scholz, T.; De Chambrier, A.; Beletew, M. and Mahmoud, Z.N. (2009): Redescription of Proteocephalus glanduligerus (Cestoda: Proteocephalidea), a parasite of clariid catfishes in Africa with a unique glandular apical organ. J. Parasitol. 95(2): 443-449.

Scholz, T. and Salgado-Maldonado, G. (2000): The introduction and dispersal of Centrocestus formosanus (Nishigori, 1924) (Digenea: Heterophyidae) in Mexico: A review. The American Midland Naturalist 143, 185-200. DOI: $10.1674 / 00030031$

Sohn, W.M. and Chai, J.Y. (2005): Infection status with helminthes in feral cats purchased from a market in Busan, Republic of Korea. The Korean Journal of Parasitology 43, 93-100. DOI:10.3347/kjp.2005.43.3.93

Steffens, W. (2006): Freshwater fish - wholesome foodstuffs. Bulgaria Journal of Agricultural Science 12: 320-328.

Subasinghe, R.P.; Bondad-Reantaso, M.G. and McGladdery, S.E. (2001): Aquaculture development, health and wealth. In: Subasinghe RP, Bueno P, Phillips MJ, Hough C, McGladdery SE, Arthur JR (eds.) Aquaculture in the Third Millennium. Technical Proceedings of the Conference on Aquaculture in the Third Millennium, Bangkok, Thailand, 20-25 February 2000. NACA, Bangkok and FAO, Rome, pp 167191.

Wedl, K. (1861): Zur Helminthen fauna Ägyptens. 2. Abtheilung, III. Nematoda. Sitzungsberichte der Kaiser Akademie der Wissenschaften und der Wienn, MathematischNaturwissenschaftlichen Classe, 44: 463-482.

Woo, P.T.K. (1995): Fish diseases and disorders. Volume I: Protozoan and Metazoan infections, CAB International, Wallingford, Oxon, U.K

Woodland, W.N.F. (1923): On some remarkable new forms of Caryophyllaeidae from the AngloEgyptian Sudan, and a revision of the families of the Cestodaria. Quarterly Journal of the Microscopical Science (New Series) 67: 435472.

Yousif, F.; Ayoub, M.; Tadros, M. and El Bardicy, S (2016): The first record of Centrocestus formosanus (Nishigori, 1924) (Digenea: Heterophyidae) in Egypt. Experim. Parasitol. 168: 56-61. 


\section{الاصابات الطفيلية والتغيرات النسيجية المرضية فى نوعين من القراقير (اسماك الثال ) بيحيرة ناصر - مصر \\ عواطف حامد حمولة}

E-mail: awatefhamouda@yahoo.com; awatefhamouda@aswu.edu.eg Assiut University web-site: www.aun.edu.eg

تم فى هذه الدر اسة استبيان الاصابات الطفيلية فى نوعين من اسمالك الثال (سينو نتنس سر اتس وسينو دنتس شال) بيحيرة ناصر وتقييم

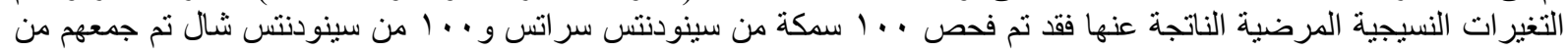

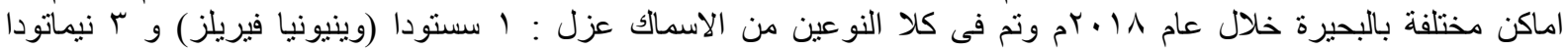

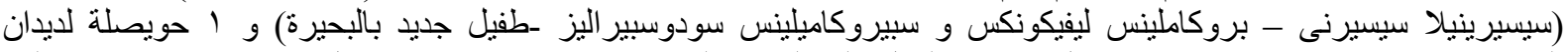

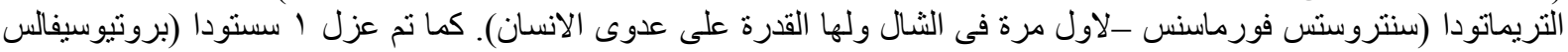

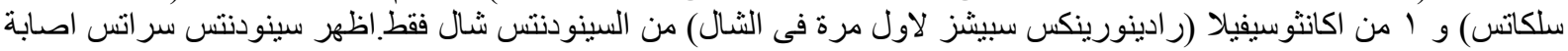

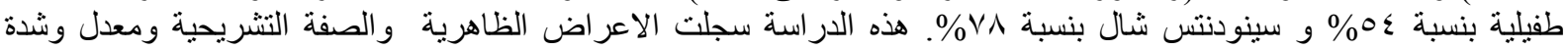

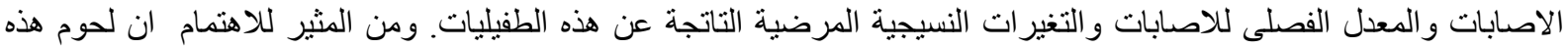

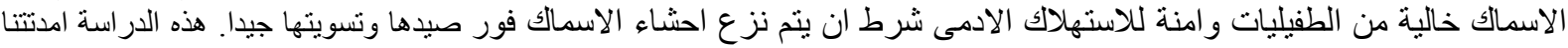

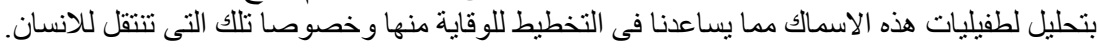

